\title{
Erratum to: Serum B cell-activating factor (BAFF) level in connective tissue disease associated interstitial lung disease
}

\author{
Tsutomu Hamada', Takuya Samukawa', Tomohiro Kumamoto', Kazuhito Hatanaka², Go Tsukuya', \\ Masuki Yamamoto ${ }^{1}$, Kentaro Machida', Masaki Watanabe', Keiko Mizuno', Ikkou Higashimoto', \\ Yoshikazu Inoue ${ }^{3}$ and Hiromasa Inoue ${ }^{1 *}$
}

\section{Erratum}

After the publication of this work [1], it was brought to the authors attention that statements in the article are not consistent with Fig. 1. The statement "Our findings show that patients who met Kinder's criteria for UCTD had significantly higher serum BAFF levels than patients with CFIP;" and "In summary, increased levels of BAFF were found in the circulation of patients with CTD-ILD and UCTD-ILD, in whom serum levels were inversely correlated with lung function" are not a correct reflection of the results from the data analysis in Fig. 1 of the article.

The corrected statements are provided here as follows: "Our findings show that patients who met Kinder's criteria for UCTD tended to have higher serum BAFF levels than patients with CFIP;" and "In summary, increased levels of BAFF were found in the circulation of patients with CTD-ILD, in whom serum levels were inversely correlated with lung function."

\section{Author details}

'Department of Pulmonary Medicine, Graduate School of Medical and Dental Sciences, Kagoshima University, 8-35-1 Sakuragaoka, Kagoshima 890-8520, Japan. ${ }^{2}$ Department of Molecular and Cellular Pathology, Graduate School of Medical and Dental Sciences, Kagoshima University, Kagoshima, Japan. ${ }^{3}$ Clinical Research Center, National Hospital Organization Kinki-Chuo Chest Medical Center, Osaka, Japan.

Received: 18 July 2016 Accepted: 2 August 2016

Published online: 08 August 2016

\section{Reference}

1. Hamada T, Samukawa T, Kumamoto T, Hatanaka K, Tsukuya G, Yamamoto M, Machida K, Watanabe M, Mizuno K, Higashimoto I, Inoue Y, Inoue H. Serum B cell-activating factor (BAFF) level in connective tissue disease associated interstitial lung disease. BMC Pulm Med. 2015;15:110. doi:10.1186/ s12890-015-0105-0.
* Correspondence: inoue-pulm@umin.net

'Department of Pulmonary Medicine, Graduate School of Medical and Dental Sciences, Kagoshima University, 8-35-1 Sakuragaoka, Kagoshima 890-8520, Japan

Full list of author information is available at the end of the article
Submit your next manuscript to BioMed Central and we will help you at every step:

- We accept pre-submission inquiries

- Our selector tool helps you to find the most relevant journal

- We provide round the clock customer support

- Convenient online submission

- Thorough peer review

- Inclusion in PubMed and all major indexing services

- Maximum visibility for your research

Submit your manuscript at www.biomedcentral.com/submit (c) 2016 The Author(s). Open Access This article is distributed under the terms of the Creative Commons Attribution 4.0 International License (http://creativecommons.org/licenses/by/4.0/), which permits unrestricted use, distribution, and reproduction in any medium, provided you give appropriate credit to the original author(s) and the source, provide a link to the Creative Commons license, and indicate if changes were made. The Creative Commons Public Domain Dedication waiver (http://creativecommons.org/publicdomain/zero/1.0/) applies to the data made available in this article, unless otherwise stated. 